\title{
THE GEOMETRY OF SOLAR RADIATION ENERGY EQUILIBRIUM DISTRIBUTION ON DOUBLE-PASS SOLAR AIR HEATER WITH THE ADDITION OF FIN ELEMENTS: CASE STUDY IN LIBYA
}

\author{
Budhi Muliawan Suyitno*, Erlanda Augupta Pane, La Ode Mohammad Firman, Abdelhafed Abuzreba, Ismail \\ Universitas Pancasila, Jakarta, Indonesia
}

The drying process is the most important process in the Libyan agricultural sector for agricultural products export value. Libya uses a direct drying system from solar radiation, but it provides a large energy loss and decreases the agricultural products quality. Solar air heater technology was developed to solve these problems. One indicator of the solar air heater performance is influenced by the solar radiation energy absorption distribution to heat the airflow, which can be seen from the changes in air temperature and influences the thermal efficiency. The addition of fin elements can optimize these mechanisms. This research was conducted to analyze the effect of fin elements (geometry and fin number) on air temperature rise through three methods i.e. measurement of air flow characteristics, heat transfer rate and thermal efficiency of solar air heater. The results showed that fin elements with a length of $1 \mathrm{~m}$ and a high range between $0.197 \mathrm{~m}$ to $0.221 \mathrm{~m}$ and the fin number of 10 pieces were able to increase the air temperature from $35^{\circ} \mathrm{C}$ to $71.8^{\circ} \mathrm{C}$ so that the thermal efficiency of solar air heater reached $51.5 \%$. The performance of this technology can be applied to the agricultural products drying process in Libya.

Key words: energy balance, fins geometry, fins number, solar air heater, thermal efficiency

\section{INTRODUCTION}

Drying agricultural products is an important process in Libya's agricultural sector, because Libya's dry agricultural products have a high export value on the international market, and are able to increase Libya's gross domestic product (GDP) value by $12.1 \%$ [1]. The working principle of drying is to reduce the product moisture content to reach a safe level through the evaporation process by controlling heat energy from solar radiation as an energy source so that the saving life of products is longer and easier [2-4]. The solar radiation energy each region is different because it depends on the conditions of the solar irradiance tilt angle, and latitude of a country [5-7]. Libya has a latitude of $32.9^{\circ} \mathrm{N}$ and a sunshine slope of $34.10^{\circ}$, where this condition can receive solar radiation energy of $2300 \mathrm{kWh} / \mathrm{m}^{2} /$ year up to $2956.5 \mathrm{kWh} / \mathrm{m}^{2} /$ year with a sunshine duration of 3500 hours/year $[6,8,9]$.

The energy potential of solar radiation can improve the drying process of agricultural products [5]. The drying process in Libya still uses conventional methods through direct drying under the sun, however, this drying process has some disadvantages, among others, its dependence on weather conditions which causes an increase in solar radiation energy losses, and agricultural products are attacked by insects and thus reduce the agricultural products quality [10]. One of the technologies that can be utilized for the drying process in Libya is the technology of solar air heater, where this technology uses indirect drying process that utilizes the solar radiation energy absorption to heat the airflow so that the air flow temperature increases $[11,12]$ then the air flow can be used for the drying process of agricultural products. The solar air heater technology can be shown in Figure 1.

The solar air heater has main parts among others are air flow ducts, glass cover, absorbent plate, and insulation plate $[15,16]$. Based on these parts the solar air heater is divided into two types i.e. single-pass and double-pass [17-19]. The single-pass uses an air flow mechanism through the top or bottom of the absorbent plate from the inlet to the outlet of the solar air heater [20]. The double-pass type uses an air flow mechanism through two types of flow i.e. counter-flow or parallel-flow where the air flow through the top as the solar air heater inlet and the absorbent plate bottom as the solar air heater outlet so that the air flows twice, therefore the airflow utilizes solar radiation energy optimally [20]. Both types of solar air heater have different efficiency levels, where double-pass types have a higher efficiency level of $10 \%$ to $15 \%$ compared to the single-pass efficiency $[15,20,21]$.

Some research have also developed the solar air heater design by adding fin elements to the absorbent plate part. The design development with the addition of fin elements to expand the heat energy absorption field area

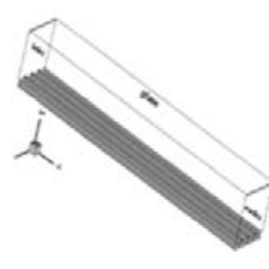

a)

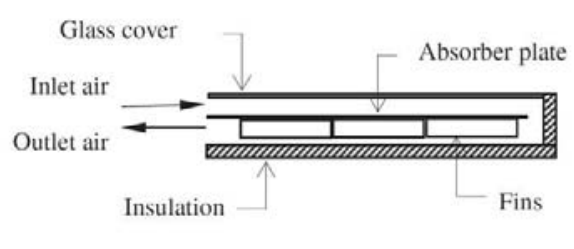

b)
Figure 1: Solar air heater design a) single-pass and b) double-pass $[13,14]$ 
from solar radiation has the aim of increasing the solar air heater outlet air flow temperature so that it influences the thermal efficiency rises of the solar air heater and can be used for drying agricultural products. The modification of fin elements that have waveforms by changing the length and amplitude of fin elements, where it can increase the amplitude and length reduction of the fin element which produce a solar air heater thermal efficiency of $78.6 \%$ to $78.8 \%$ [22]. The addition of fin elements using the type of offset where each increase in distance and height of the offset fin elements resulted in an increase in thermal efficiency of the solar air heater starting from $30.56 \%$ to $74.57 \%$ [23]. The utilization of fin elements with three types among others are rectangular, triangular, and elliptical, where the rectangular fin type produces the higher thermal efficiency of $5.5 \%$ to $12.5 \%$ compared to the other two types of fins [13]. The fin elements made changes the geometry using the herringbone corrugated type, where this type uses zig-zag-shaped fin elements to obtain a thermal efficiency of $71.4 \%$ [24]. The effect analysis of fin elements by the number and height factor of fin elements, where the increasing number of fin elements was able to increase the thermal efficiency of solar air heater by $60 \%$, while an increase in fin elements height could reduce thermal efficiency by $35 \%$ [25]. The solar air heater used a transverse type fin element on a single-pass and double-pass types, where the double-pass has a higher thermal efficiency of $15 \%$ compared to a single-pass [15].

Based on some previous fin elements research can be explained that fin elements most influence the thermal efficiency condition of solar air heater. This research was conducted to analyze the fin elements effect applied to the absorbent plate to increase the air temperature at the outlet of the solar air heater by using fin geometry factors (length and height) and the fin elements number adjusted to the solar radiation energy conditions in Libya. The aims of research are to produce the optimum air temperature for the drying process of agricultural products, and increasing the thermal efficiency of solar air heat- ers applied in Libya. The research method is carried out through the calculation of energy equilibrium in the heat transfer process in the solar air heater, and calculation of thermal efficiency.

\section{METHOD}

This research analyzes the performance of double-pass type solar air heater with counter flow conditions that have a material composition with the ability to absorb solar radiation energy optimally, which is adjusted to Libyan conditions. The solar air heater with double-pass type can be seen in Figure 2.

The Solar Air Heater has four parts, among others are airflow ducts, glass cover, absorbent plate, and insulation plate $[15,16]$. The addition of fin elements to the absorbent plate section was the main factor of research in determining the solar air heater performance. The material composition of the double-pass type solar air heater (Figure 2) can be seen in Table 1.

Based on Table 1 can be explained that the glass cover

Table 1: Material of double-pass solar air heater

\begin{tabular}{|c|c|c|c|}
\hline No. & Parts & Dimension $(\mathrm{L} \times \mathrm{W} \times \mathrm{H})$ & Materials \\
\hline 1. & Glass cover & $1.2 \mathrm{~m} \times 0.8 \mathrm{~m} \times 0.004 \mathrm{~m}$ & Glass \\
\hline 2. & Absorber plate & $1.0 \mathrm{~m} \times 0.8 \mathrm{~m} \times 0.003 \mathrm{~m}$ & Copper \\
\hline 3. & Fins element & $1.0 \mathrm{~m} \times 0.06 \mathrm{~m} \times 0.018 \mathrm{~m}$ & Copper \\
\hline 4. & Insulation plate & & \\
& a. Left side & $1.1 \mathrm{~m} \times 0.04 \mathrm{~m} \times 0.11 \mathrm{~m}$ & Cork \\
& b. Right side & $1.1 \mathrm{~m} \times 0.04 \mathrm{~m} \times 0.11 \mathrm{~m}$ & Cork \\
& c. Back side & $1.1 \mathrm{~m} \times 0.04 \mathrm{~m} \times 0.11 \mathrm{~m}$ & Cork \\
\hline
\end{tabular}

uses glass material which has a high heat transmission coefficient of $0.935[26,27]$, where the coefficient makes the glass cover absorb and collect enough solar radiation energy for heating the primary air flow on the inlet section of the solar air heater. The absorbent plate material uses copper material with a heat conductivity rate of $400 \mathrm{~W} / \mathrm{mK}$ [28]. The high rate of thermal conductivity makes the absorbent plate absorb solar energy directly from the environment or solar radiation energy which

Site latitude of Libya is 30.32 degrees

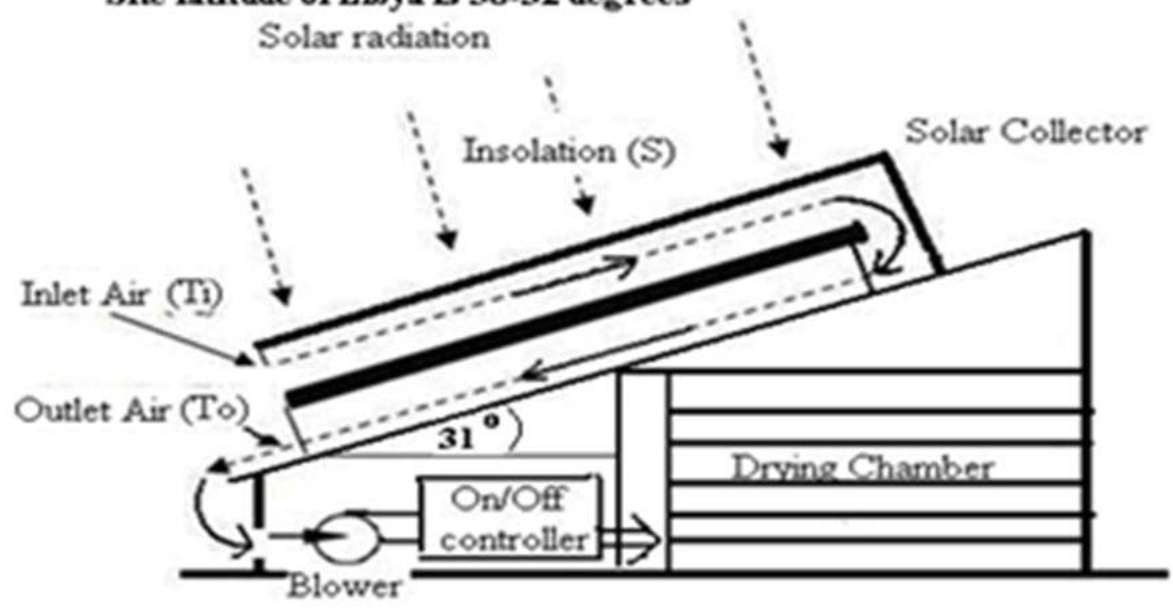

Figure 2: The solar air heater with double-pass type 
s not utilized on the primary air flow heating process. The addition of fin elements applied on the absorbent plate also increases the area of solar thermal radiation energy absorption towards secondary airflow on the outlet section of the solar air heater [29]. The fin elements utilization is also influenced by the fin geometry (lengthheight) and the fin number. The cork utilization as insulation plates can reduce the energy losses because of the viscoelastic cork characteristics, and impermeable to liquids or gases, moreover this material has a low thermal conductivity rate of $0.063 \mathrm{~W} / \mathrm{mK}$ up to $0.065 \mathrm{~W} / \mathrm{mK}$

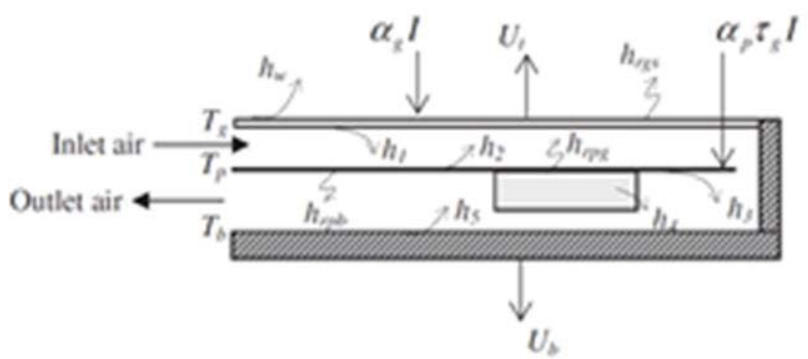

Figure 3: The working principle of double-pass solar air heater [16]

Glass cover:

$\alpha_{g} I+\left(h_{r, p g}+h_{c, p g}\right)\left(T_{p}-T_{g}\right)=\left(h_{w}+h_{r, g a}\right) T_{a}$

Absorbent plate:

$$
\begin{aligned}
& I \alpha_{p} \tau_{g}=\left(h_{r, p g}+h_{c, p g}\right)\left(T_{p}-T_{g}\right)+h_{r, p b}\left(T_{p}-T_{g}\right) \\
& +h_{c, g f}\left(T_{p}-T_{f}\right)+\frac{N}{A_{p}}\left(-k_{f n} A_{f n} \frac{d T_{f n}}{d y}\right)_{y=0}
\end{aligned}
$$

Insulation plate:

$h_{r, p b}\left(T_{p}-T_{b}\right)+h_{c, p b}\left(T_{f}-T_{b}\right)=U_{b}\left(T_{b}-T_{a}\right)$

Airflow:

$h_{c, g f}\left(T_{p}-T_{f}\right)+\frac{N}{A_{p}}\left(-k_{f n} A_{f n} \frac{d T_{f n}}{d y}\right)_{y=H_{f}}+\frac{N}{A_{p}} \int_{y=0}^{y=H_{f}} 2 h_{c, p f} L_{f}\left(T_{f n}-T_{f}\right) d y=2\left(\frac{\dot{m} C_{p}}{A_{p}}\right)\left(T_{f}-T_{i}\right)+h_{c, f b}\left(T_{f}-T_{b}\right)$

Fins elements:

$$
\begin{aligned}
& I \alpha_{p} \tau_{g}=\left(h_{r, p g}+h_{c, p g}\right)\left(T_{p}-T_{g}\right)+h_{r, p b}\left(T_{p}-T_{b}\right)+h_{c, p f}\left(T_{p}-T_{f}\right)+\left(\frac{N A_{3}}{A_{p}}\right)\left(T_{p}-T_{f}\right) \\
& h_{c, p f}\left(T_{p}-T_{f}\right)+\left(\frac{N A_{3}}{A_{p}}\right)\left(T_{p}-T_{f}\right)=2\left(\frac{\dot{m} C_{p}}{A_{p}}\right)\left(T_{f}-T_{i}\right)+h_{c, f b}\left(T_{f}-T_{b}\right)
\end{aligned}
$$

Where:

$$
\begin{aligned}
& A_{3}=\frac{m k_{f n} A_{f n}\left[\sinh A_{1}+A_{2} \cosh A_{1}\right]}{\cosh A_{1}+A_{2} \sinh A_{1}} \\
& A_{1}=m H_{f ;}, A_{2}=\frac{h_{c, p f}}{m k_{f n}} \\
& y=0 ; T_{f n}=T_{p} \\
& y=H_{f} \\
& h_{c, p f} A_{f n}\left(T_{f n}\left(H_{f}\right)-T_{f}\right)=-k_{f n} A_{f n}\left(\frac{d T_{f n}}{d y}\right)_{y=H_{f}}
\end{aligned}
$$


fluenced by geometry (height-length) and number of fin elements. These factors affect the circulation condition of air flow around the absor-bent plate and fin elements area. The energy balance mechanism in fin elements can be shown in Figure 4.

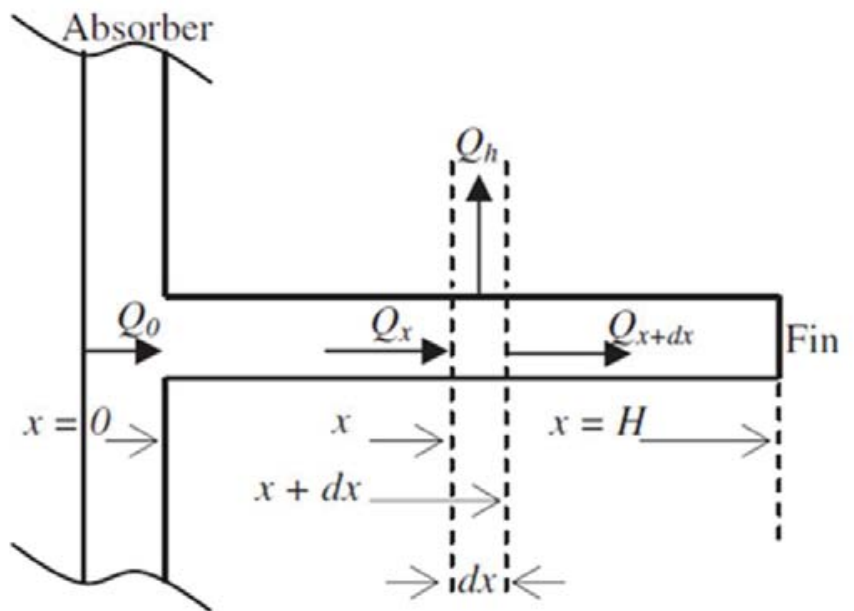

Figure 4: Energy balance scheme of fin elements

Based on Figure 4 is explained that the heat energy of solar radia-tion driving from the absorbent plate to the fin element which the solar radiation energy is able to heat the air flow in the end plate of fin element $[32,33]$ The energy equilibrium conditions in the solar air heater system described in Equation 1 until Equation 7 are influenced by the temperature parameters in each part of the solar air heater and air flow temperature, which can be measured using Equations 8 to Equation 11 [24].

Glass cover:

$T_{g}=\frac{\alpha_{g} I+\left(h_{r, p g}+h_{c, p g}\right) T_{p}+\left(h_{w}+h_{r, g a}\right) T_{a}}{h_{r, p g}+h_{c, p g}+h_{w}+h_{r, g a}}$

Insulation plate:

$T_{b}=\frac{U_{b} T_{a}+h_{r, p b} T_{b}+h_{c, f b} T_{f}}{h_{r, p b}+h_{c, f b}+U_{b}}$

Absorbent plate:

$T_{p}=\frac{I \alpha_{p} \tau_{g}+\left(h_{r, p g}+h_{c, p g}\right) T_{g}+h_{r, p h} T_{b}+\left(h_{c, p f}+\left(N A_{3} / A_{p}\right)\right) T_{f}}{h_{r, p g}+h_{c, p g}+h_{r, p b}+h_{c, p f}+\left(N A_{3} / A_{p}\right)}$

Airflow:

$T_{f}=\frac{\left(h_{c, p f}+\left(N A_{3} / A_{p}\right)\right) T_{p}+2\left(\dot{m} c_{p} / A_{p}\right) T_{i}+h_{c, f b} T_{b}}{h_{c, p f}+\left(N A_{3} / A_{p}\right)+2\left(\dot{m} c_{p} / A_{p}\right)+h_{c, f b}}$

Meanwhile, the condition of the air temperature at the outlet section of the solar air heater can be determined by Equation 12[18].

$$
\frac{T_{f o}-T_{a}-S / U_{L}}{T_{f t}-T_{a}-S / U_{L}}=\exp \left[\frac{-A_{c} U_{L} F^{\prime}}{\dot{m} C_{p}}\right]
$$

\section{Thermal Efficiency}

The total energy used in heat transfer process is calculated, where it is explained in the form of air mass flow rates, specific air heat and differences in air temperature between the inlet and outlet, where the calculations by Equation 13 [18,22].

$$
Q_{u}=\dot{m} C_{p}\left(T_{f o}-T_{f i}\right)
$$

Where,

$$
\begin{aligned}
& \left(T_{f o}-T_{f i}\right)=\left(\frac{S-U_{L}\left(T_{f i}-T_{a}\right)}{U_{L}}\right)\left(1-\exp \left(\frac{-A_{c} F^{\prime} U_{L}}{m C_{p}}\right)\right) \\
& F^{\prime}=\frac{h_{e}}{h_{e}+U_{L}} \\
& h_{e}=h_{f}+\frac{h_{r} \cdot h_{f}}{h_{r}+h_{f}} \\
& U_{L}=U_{t}+U_{b} \\
& \eta_{t h}=\frac{Q_{u}}{A_{c} \cdot I}
\end{aligned}
$$

\section{RESULTS AND DISCUSSION}

The energy potential of solar radiation can be used as an energy source in the drying process of agricultural products in Libya. However, the conventional drying process that utilizes radiation energy directly still has a large level of solar radiation energy losses which decrease the agricultural products quality. The utilization of solar radiation energy potential by using solar air heater technology is the possible solution because the solar air heater is able to collect and distribute solar radiation energy to heat the air flow in the solar air heater pipe ducts as a heat source in the drying process of agricultural products. Increasing the air flow temperature that occurs in the inlet to the outlet section of the solar air heater can explain the solar radiation energy distribution effectiveness in the solar air heater system as a performance parameter of the solar air heater.

The air flow type passes the solar air heater pipe duct uses the counter flow concept, where the concept is able to heat the airflow twice at the top and bottom of the solar air heater. The air flow rate at the top section gets solar radiation energy through the collector plate, while the air flow rate at the bottom section gets solar radiation energy through absorbent plates and fin elements. The solar air heater system works in conditions adapted to the Libyan environment, where the inlet air temperature has the same value as the ambient air temperature of $35^{\circ} \mathrm{C}$. The air temperature has increased at the end of the top pipe ducts section by $44.5^{\circ} \mathrm{C}$. Then, the air temperature is increased again at the bottom section so that it gets an air temperature in the outlet section of $71.8^{\circ} \mathrm{C}$. Based on the results of the air temperature rises in the solar air heat- 
er outlet, it can be explained that the addition of fin elements on the absorbent plate is important in the solar air heater system, because fin elements can increase the absorption area of solar radiation energy which comes from the energy residue output of solar radiation that is not utilized in the heating process of airflow at the top of the solar air heater or radiation energy directly from sunlight so as to increase the air temperature twice compared to the increase in air temperature on the top of the solar air heater. The effect of air velocity and air flow rate also influences the solar radiation energy distribution to air flow. The results of the airflow temperature on the solar air heater outlet towards the parameters of air velocity and air flow rate as results of Equation 11 can be seen in Figure 5.

Based on Figure 5 can be explained that the optimum conditions of energy solar radiation distribution for the air heating process occur at an air flow rate of $0.05 \mathrm{~kg} / \mathrm{s}$ and an air velocity of $0.5 \mathrm{~m} / \mathrm{s}$. The magnitude of air flow velocity and minimum air flow rate make solar radiation energy absorption more effective, due to an increase in the airflow area to absorb solar radiation energy. The energy losses factor of solar radiation to be used in the heating process of air flow also decreases due to the increase in the absorption area of solar radiation energy which causes friction between the air flow and the surface of

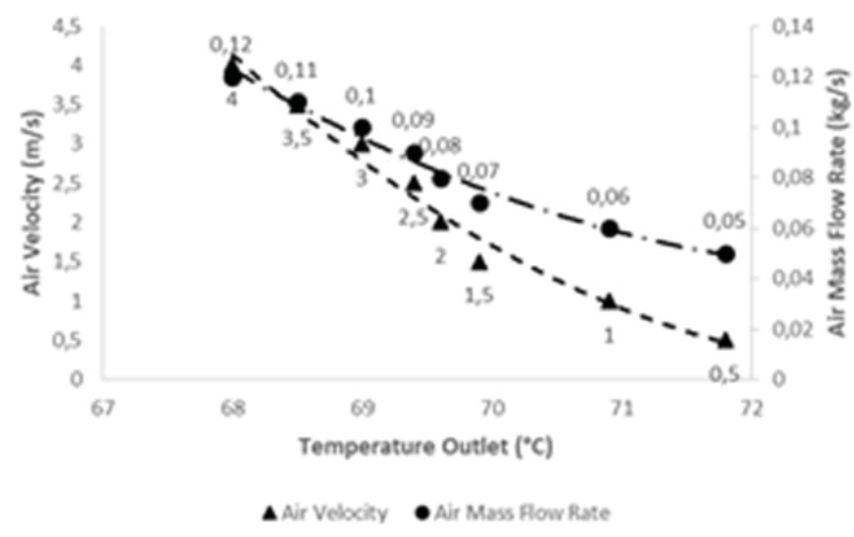

Figure 5: Correlation of solar air temperature, air flow rate, and air velocity

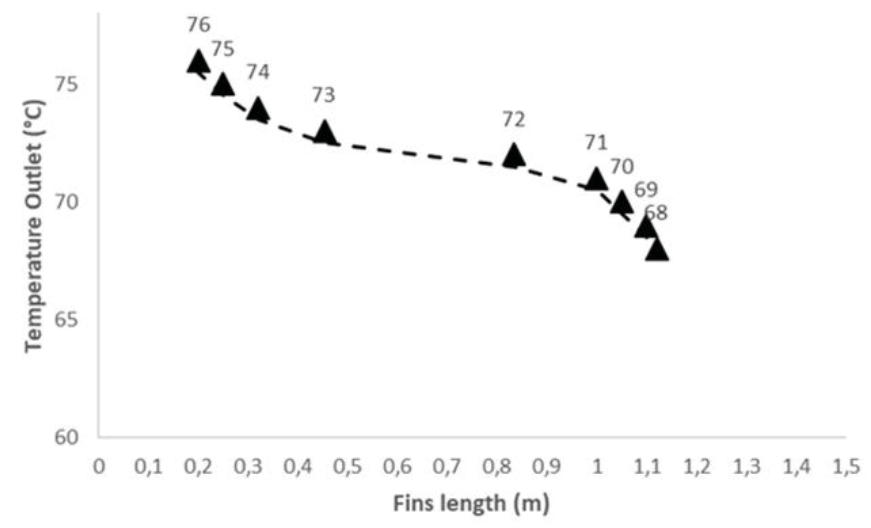

Figure 6: Effect of fin element length on air outlet temperature the solar air heater pipeline to decrease. In addition to the outlet air temperature condition, the air temperature conditions in some parts of the solar air heater can be analyzed by the equations calculation among others are air temperature in the collector plate, absorbent plate, top-bottom section pipe duct, and insulation plate, where it can be shown by equation 8 until equation 11 . The calculation results can be seen in Table 2.

Table 2: Air temperature condition on solar air heater parts

\begin{tabular}{|c|c|}
\hline Parts & Temperature $\left({ }^{\circ} \mathrm{C}\right)$ \\
\hline Glass cover $\left(\mathrm{T}_{\mathrm{g}}\right)$ & 97.59 \\
\hline Primary air flow $\left(\mathrm{T}_{\mathrm{f} 1}\right)$ & 43.45 \\
\hline Absorbent plate + Fin elements $\left(\mathrm{T}_{\mathrm{p}}\right)$ & 130.13 \\
\hline Secondary air flow $\left(\mathrm{T}_{\mathrm{f} 2}\right)$ & 71.80 \\
\hline Insulation plate $\left(\mathrm{T}_{\mathrm{b}}\right)$ & 74.27 \\
\hline
\end{tabular}

Based on Table 2 can be explained that the solar radiation energy capable of heating the glass cover reaches a temperature $\left(T_{q}\right)$ of $97.59^{\circ} \mathrm{C}$. The high temperature of the glass cover is used for the heating process of primary airflow $\left(T_{f 1}\right)$ at the the solar air heater pipe duct top section with an inlet temperature of $35^{\circ} \mathrm{C}$ to $43.45^{\circ} \mathrm{C}$. The temperature of the absorbent plate and fin element $\left(T_{p}\right)$ has a value of $130.13^{\circ} \mathrm{C}$, this occurs because the absorbent plates and fin elements have a wider area of solar radiation energy absorption compared to the collector plate capable of absorbing residue solar radiation energy from the heating process on the top section or directly from the solar light. The temperature of the insulation plate $\left(T_{b}\right)$ has a value of $74.27^{\circ} \mathrm{C}$, where it can be explained that the heat energy produced by the air flow has been limited to the insulation plate thereby reducing energy losses from the air flow. In addition, it can be said that the solar air heater system has a closed condition without any leakage that causes energy to go out into the environment.

The utilization of fin elements in expanding the absorption area of solar radiation energy in the absorbent plate part is influenced by several factors, among others are

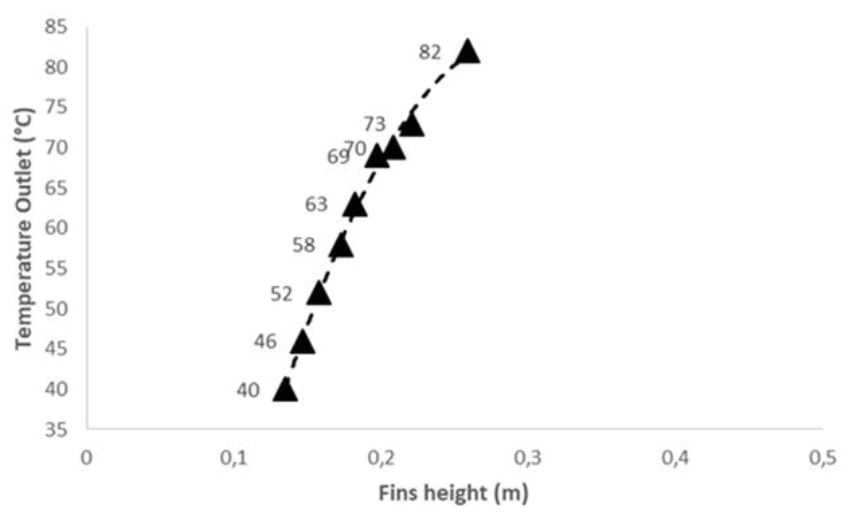

Figure 7: Effect of fin element height on air outlet temperature 
the geometry of fin elements (length and height) and the utilization of fin elements number. The factors as a parameter to measure the Equation 11. Each factor has a different effect on the temperature conditions of the airflow where the results of the conditions can be shown in Figure 6, 7, and 8 respectively.

Figure 6 and Figure 7 can show that the length geometry and height of fin elements needed to produce air outlet temperatures of $71.8^{\circ} \mathrm{C}$ are $1 \mathrm{~m}$ and between $0.197 \mathrm{~m}$ up to $0.221 \mathrm{~m}$ respectively. Based on Figure 6 can also be explained that the addition of fin element length can reduce the air outlet temperature because the distributed solar radiation energy has a small magnitude, where this condition is related to the conduction activity between the fin elements to the air flow. Based on Figure 7 it can also be explained that the addition of fin elements can increase the temperature of the air outlet where this condition is also related to conduction activity, especially in the condition of the heat transfer area between fin elements and airflow. However, increasing the air outlet temperature have a negative effect on the drying process of agricultural products, so it is necessary to control the air outlet temperature. In addition to the fin geometry (length and height), the fin elements number used can be taken into consideration in terms of increasing the absorption area of solar radiation energy. The effect of the fin elements number on the airflow outlet temperature can be seen in Figure 8.

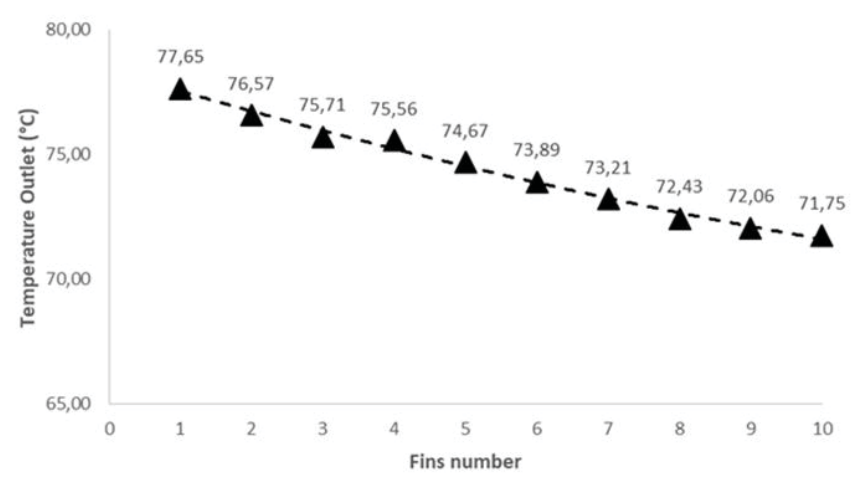

Figure 8: Effect of fin elements number on air outlet temperature

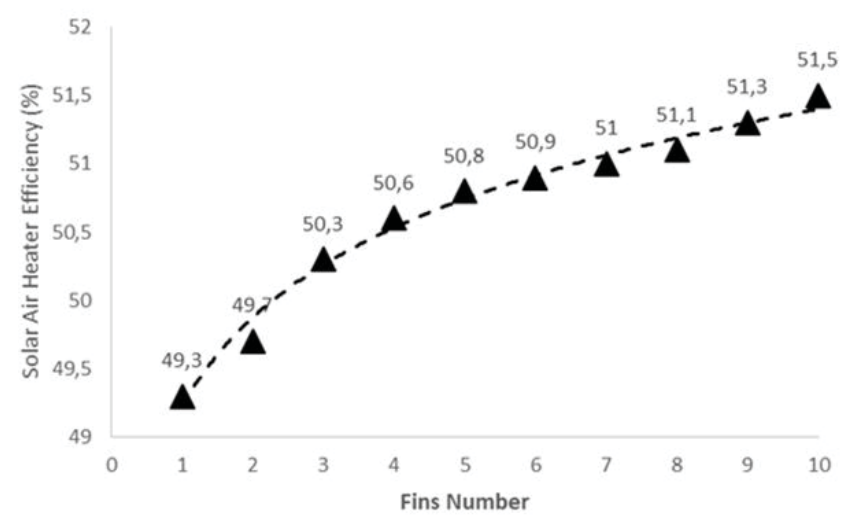

Figure 9: Comparison of fin elements number to the thermal efficiency of solar air heater
Figure 8 shows that the fin elements number of 1 piece produces an air outlet temperature of $77.65^{\circ} \mathrm{C}$, while a fin element of 10 pieces only produces an air outlet temperature of $71.75^{\circ} \mathrm{C}$. This condition occurs because of the fin elements numbers effect as same as the impact on the fin element length. However, if it is connected with the thermal efficiency condition of the solar air heater shown in Figure 9 can be explained that the increase fin elements can increase the thermal efficiency of the solar air heater. Based on Figure 9 can be seen that the number of fin elements of 10 pieces can produce a thermal efficiency of $51.5 \%$, where it was calculated by Equation 18. This condition occurs because the displacement and distribution of solar radiation energy is evenly distributed in each fin element related with airflow compared to one fin element which makes the process of transferring solar radiation energy centered on one distribution area where the airflow temperature would decrease at the outlet solar air heater, and the air temperature is not optimum for the drying process of agricultural products. This whole process can be shown in Figure 10.

The thermal efficiency produced by the solar air heater explains the hot airflow level for the drying process of agricultural products in Libya.

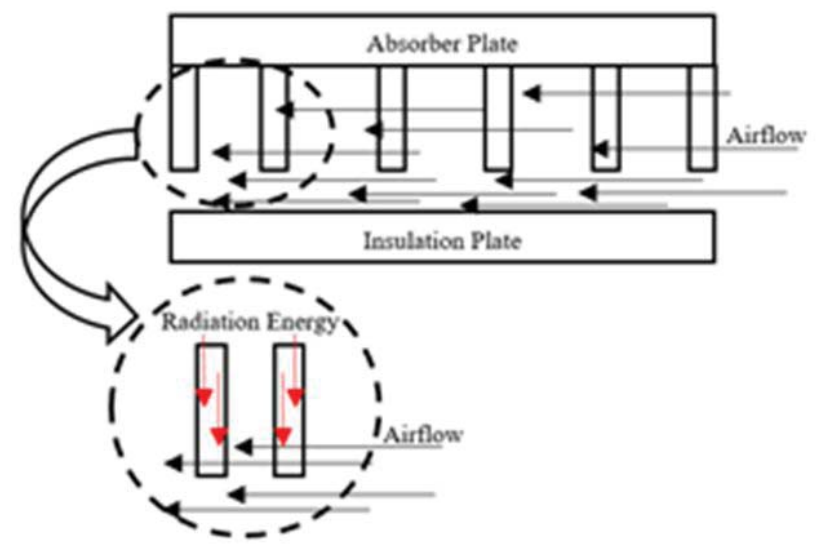

a)

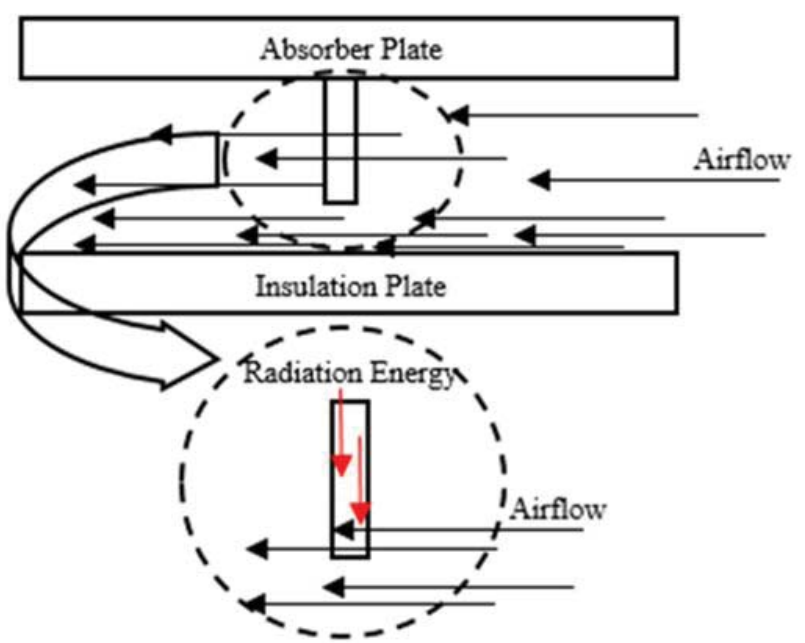

b)

Figure 10: Heat transfer process on multiple fin elements (a) and single fin elements (b) 


\section{CONCLUSION}

The research results can be concluded that the addition of fin elements to the absorbent plate as a part of the double-pass type solar air heater can increase the air temperature rapidly. The fin elements has a long geometry of $1 \mathrm{~m}$, a height range of $0.197 \mathrm{~m}$ to $0.221 \mathrm{~m}$, and numbers of fin elements of 10 pieces. This design can present the better performance of solar air type, where it can shows the rise of air temperature from $35^{\circ} \mathrm{C}$ to $71.8^{\circ} \mathrm{C}$. This condition also increases the thermal efficiency of $51.5 \%$. This design can be a conventional drying methods in Libya.

\section{ACKNOWLEDGEMENT}

The authors are grateful to the mechanical engineering laboratory, the University of Pancasila, Indonesia.

\section{NOMENCLATURES}

$A_{c}$ - Glass cover area $\left(\mathrm{m}^{2}\right)$

$A_{p}$ - Area of absorbent plate $\left(\mathrm{m}^{2}\right)$

$A_{f n}$ - Fins area $\left(\mathrm{m}^{2}\right)$

$C p$ - specific of heat air $(\mathrm{J} / \mathrm{kgK})$

$F^{\prime}$ - collector efficiency factor

$H_{f}$ - Fins height (m)

$h_{w}$ - Heat transfer coefficient due to wind at the top of cover

$h_{e}$ - Effective heat transfer coefficient $\left(\mathrm{W} / \mathrm{m}^{2} \mathrm{~K}\right)$

$h_{f}$ - Convective heat transfer coefficient of air $\left(\mathrm{W} / \mathrm{m}^{2} \mathrm{~K}\right)$

$h_{r}$ - Radiative heat transfer coefficient $\left(\mathrm{W} / \mathrm{m}^{2} \mathrm{~K}\right)$

$h_{r, g a}$ - Radiative heat transfer coefficient between glass cover and ambient $\left(\mathrm{W} / \mathrm{m}^{2} \mathrm{~K}\right)$

$h_{r, p b}$ - Radiative heat transfer coefficient between absorber plate and insulation plate $\left(\mathrm{W} / \mathrm{m}^{2} \mathrm{~K}\right)$

$h_{r, p g}$ - Radiative heat transfer coefficient between glass cover and absorbent plate $\left(\mathrm{W} / \mathrm{m}^{2} \mathrm{~K}\right)$

$h_{c, p g}$ - Convective heat transfer coefficient between absorber plate and glass cover $\left(\mathrm{W} / \mathrm{m}^{2} \mathrm{~K}\right)$

$h_{c, p f}$ - Convective heat transfer coefficient between insulation plate and fluid $\left(\mathrm{W} / \mathrm{m}^{2} \mathrm{~K}\right)$

$h_{c, f b}$ - Convective heat transfer coefficient between insulation plate and fluid $\left(\mathrm{W} / \mathrm{m}^{2} \mathrm{~K}\right)$

I - Radiation intensity $\left(\mathrm{W} / \mathrm{m}^{2}\right)$

$k_{f n}$ - Thermal conductivity of fins $(\mathrm{W} / \mathrm{mK})$

$L_{f}$ - Extended length of fins (m)

$\dot{m}$ - Mass flow rate $(\mathrm{kg} / \mathrm{s})$

$N$ - Number of fins

$Q_{u}$ - Useful thermal energy gain $\left(\mathrm{W} / \mathrm{m}^{2}\right)$

$S$ - Absorbed solar energy $\left(\mathrm{W} / \mathrm{m}^{2}\right)$

$v$ - Air velocity $(\mathrm{m} / \mathrm{s})$

$T_{\alpha}$ - Ambient temperature (K)

$T_{b}$ - Mean temperature of insulation plate $(\mathrm{K})$
$T_{f}$ - Mean temperature of fluid $(\mathrm{K})$

$T_{f i}$ - Inlet air temperature $(\mathrm{K})$

$T_{\text {fo }}$ - Outlet air temperature (K)

$T_{f n}$ - Mean temperature of fins (K)

$T_{g}$ - Mean temperature of glass cover $(\mathrm{K})$

$T_{i}$ - Inlet fluid temperature $(\mathrm{K})$

$T_{p}$ - Mean absorbent plate temperature $(\mathrm{K})$

$U_{b}$ - bottom heat loss coefficient $(\mathrm{W} / \mathrm{m} 2 \mathrm{~K})$

$U_{L}$ - Total loss coefficient $\left(\mathrm{W} / \mathrm{m}^{2} \mathrm{~K}\right)$

$U_{t}$ - Top loss coefficient $\left(\mathrm{W} / \mathrm{m}^{2} \mathrm{~K}\right)$

$\alpha_{p}$ - Absorptivity of absorbent plate

$\alpha_{g}$ - Absorptivity of glass cover

$\eta_{t h}$ - Thermal efficiency of solar air heater

\section{REFERENCES}

1. Lambert, D., McKoy, S. (2009). Trade creation and diversion effects of preferential trade associations on agricultural and food trade. Journal of Agricultural Economics, vol.60, 17-39.

2. Sivakumar, R., Saravanan,R., Elaya Perumal,A., Iniyan,S.(2016). Fluidized bed drying of some agro products - A review. Renewable and Sustainable Energy Reviews, vol.61, 280-301.

3. Eltawil, MA., Azam, MM., Alghannam, AO. (2018). Solar PV powered mixed-mode tunnel dryer for drying potato chips. Renewable Energy, vol.116, 594-605.

4. Sharada, S. (2013). Studies on effect of various operating parameters \& foaminglnagents - Drying of fruits and vegetables.ljmer, vol.3, 1512-1519.

5. Alosaimy, AS. (2013). Application of Evaporative Air Coolers Coupled With Solar Water Heater for Dehumidification of Indoor Air. International Journal of Mechanical \& Mechatronics Engineering IJMEE-IJENS, vol.13, 60-68.

6. Darhmaoui, H., Lahjouji, D. (2013). Latitude based model for tilt angle optimization for solar collectors in the mediterranean region. Energy Procedia. vol.42, 426-435.

7. Mkharem, M., Adam, N., Supeni, E., Mustapha, S. (2017). Fire severity prediction analysis of a traditional libya house roofing materials: A case study. Journal of Mechanical Engineering and Sciences, vol.11, 2952-2966.

8. Glaisa, KA., Elayeb, ME., Shetwan, MA. (2014). Potential of hybrid system powering school in Libya. Energy Procedia, vol.57, 1411-1120.

9. Mohamed, AMA., Al-Habaibeh, A., Abdo, H. (2013). An investigation into the current utilisation and prospective of renewable energy resources and technologies in Libya. Renewable Energy, vol.50, 732-740. 
10. Brown, B., Nuberg, I., Llewellyn, R. (2018). Constraints to the utilisation of conservation agriculture in Africa as perceived by agricultural extension service providers. Land Use Policy, vol.73, 331-340.

11. Tyagi, V., Panwar, NL., Rahim, NA., Kothari, R. (2012). Review on solar air heating system with and without thermal energy storage system. Renewable and Sustainable Energy Reviews, vol.16, 2289-2303.

12. Sansaniwal, SK., Kumar, M. (2015). Analysis of ginger drying inside a natural convection indirect solar dryer: An experimental study. Journal of Mechanical Engineering and Sciences, vol.9,1671-1685.

13. Hosseini, SS., Ramiar, A., Ranjbar, AA. (2018). Numerical investigation of natural convection solar air heater with different fins shape. Renewable Energy, vol.117: 488-500.

14. Kumar, R., Rosen, MA. (2011). Performance evaluation of a double pass PV/T solar air heater with and without fins. Applied Thermal Engineering, vol.31, 1402-1410.

15. Mahmood, AJ., Aldabbagh, LBY., Egelioglu, F. (2015). Investigation of single and double pass solar air heater with transverse fins and a package wire mesh layer. Energy Conversion and Management, vol.89, 599-607.

16. Fudholi, A., Sopian, K., Yusof, M., Hafidz, M., Bakhtyar, B. (2013). Energy analysis and improvement potential of finned double-pass solar collector. Energy Conversion and Management, vol.75, 234-240.

17. Ramani, BM., Gupta, A., Kumar, R. (2010). Performance of a double pass solar air collector. Solar Energy, vol.84, 1929-1937.

18. Priyam, A., Chand, P. (2016). Thermal and thermohydraulic performance of wavy finned absorber solar air heater. Solar Energy, vol.130, 250-259.

19. Mojumder, JC., Chong, WT., Ong, HC., Leong, KY. (2016). An experimental investigation on performance analysis of air type photovoltaic thermal collector system integrated with cooling fins design. Energy \& Buildings, vol.130, 272-285.

20. Alam, T., Kim, MH. (2017). Performance improvement of double-pass solar air heater - A state of art of review. Renewable and Sustainable Energy Reviews, vol.79, 779-793.

21. Nowzari, R., Aldabbagh, LBY., Egelioglu, F. (2014). Single and double pass solar air heaters with partially perforated cover and packed mesh. Energy, vol.73, 694-702.

22. Priyam, A., Chand, P. (2018). Effect of wavelength and amplitude on the performance of wavy finned absorber solar air heater. Renewable Energy, vol.119, 690-702.
23. Rai, S., Chand, P., Sharma, SP. (2018). Evaluation of thermo hydraulic effect on offset finned absorber solar air heater. Renewable Energy, vol.125, 39-54.

24. Kumar, R., Chand, P. (2017). Performance enhancement of solar air heater using herringbone corrugated fins. Energy,vol.127, 271-279.

25. Fan, W., Kokogiannakis, G., Ma, Z., Cooper, P. (2017). Development of a dynamic model for a hybrid photovoltaic thermal collector - Solar air heater with fins. Renewable Energy, vol.101, 816-834.

26. Good, P., Cooper, T., Querci, M., Wiik, N., Ambrosetti, G., Steinfeld, A. (2016). Spectral reflectance, transmittance, and angular scattering of materials for solar concentrators. Solar Energy Materials and Solar Cells, vol.144, 509-522.

27. Salleh, N., Shamsudin, Z., Juoi, J., Mustafa, Z. (2017). Effects of heating rates and SBE loading on sintered properties of spent bleach earth/recycled glass composite. Journal of Mechanical Engineering and Sciences, vol.11, 3104-3115.

28. Yoshida, K., Morigami, H. (2004). Thermal properties of diamond/copper composite material. Microelectronics Reliability, vol.44, 303-308.

29. Boubault, A., Ho, CK., Hall, A., Lambert, TN., Ambrosini, A. (2017). Durability of solar absorber coatings and their cost-effectiveness. Solar Energy Materials and Solar Cells, vol.166, 176-84.

30. Limam, A., Zerizer, A., Quenard, D., Sallee, H., Chenak, A. (2016). Experimental thermal characterization of bio-based materials (Aleppo Pine wood, cork and their composites) for building insulation. Energy and Buildings, vol.116, 89-95.

31. Carvalho, R., Fernandes, M., Fangueiro, R. (2017). The influence of cork on the thermal insulation properties of home textiles. Procedia Engineering, vol. 200, 252-259.

32. Naphon, P. (2005). On the performance and entropy generation of the double-pass solar air heater with longitudinal fins. Renewable Energy, vol.30, 1345-1357.

33. Alta, D., Bilgili, E., Ertekin, C, Yaldiz, O. (2010). Experimental investigation of three different solar air heaters: Energy and exergy analyses. Applied Energy, vol.87, 2953-2973.

Paper submitted: 15.04.2019.

Paper accepted: 15.04.2020.

This is an open access article distributed under the CC $B Y-N C-N D 4.0$ terms and conditions. 